\title{
A gLOBÁLIS TUdÁS PIACA
}

\author{
CSEPELI GYÖRGY
}

Eötvös Loránd Tudományegyetem

Beérkezett: 2020. október 3., elfogadva: 2021. január 14.

\begin{abstract}
A koronavírus-járvány megmutatta, hogy mennyire törékenyek az emberiség jólétének alapjai. Steven Pinkernek igaza lehet abban, hogy az emberiség még sosem élt oly jól, mint a 20. és 21. század fordulóján, de abban senki nem lehet bizonyos, hogy a trend folytatódik. A klímaváltozás, a migráció, a civilizációk békésnek nem mondható együttélése, a globális egyenlőtlenségek és a pénzügyi rendszer elszabadulása eredményeképpen planetáris idiotizmus jelent meg. A világ minden korábbi korszakhoz képest változékonyabb, bizonytalanabb, kétértelmübb és komplexebb társadalmi-természeti valósággá lett, melynek megismerése, kikutatása az egyetemeken és a kutatóintézetekben munkálkodó tudósok dolga. A vírusjárvány nyertese a digitális szféra, ahol a tudás globális piacterei nyílnak. Az emberiség jövője azon múlik, hogy visszatalál-e a szolidaritás értékeihez, melyek megtartották a Földön.
\end{abstract}

Kulcsszavakः globális válság, tudás, digitális átalakulás

The coronavirus pandemic has shown how fragile are the grounds of human wellbeing on earth. Steven Pinker can be right stating that humankind has never lived so well than at the turn of the century but no-one can be sure that this trend will not end abruptly. Climate change, migration, increase of global inequalities the belligerent coexistence of civilisations and the unleash of the financial system have resulted the emergence of planetary idiotism. The world has never been more volatile, uncertain, ambiguous and complex than before. Studying and knowing this world is the task to be done by scholars working in research institutes and universities. The winner of the coronavirus pandemic has become the digital sphere where the global marketplaces of the knowledge production and distribution operate. The future of mankind depends on the willingness to return to the primordial values of solidarity that helped the human survival.

Keywords: global crisis, knowledge, digital transformation

Levelező szerző: Csepeli György egyetemi tanár, ELTE TáTK, Budapest 1117, Pázmány P. stny. 1/1.

E-mail: csepeli.gyorgy@gmail.com 
$\mathrm{D}$ ante Isteni szinjátéka azzal kezdődik, hogy a költő az igaz utat elvétvén egy nagy sötétlő erdőbe jut, melynél a halált sem tartja sokkal rosszabbnak. Mint később megtudjuk, az út a Pokolba vezet. A 2019 telén kitört és 2020-ban világszerte még javában tartó vírusjárvány kapcsán nehéz nem arra gondolni, hogy Dante útvesztését követően 700 évvel később az emberiség vesztett utat, ám most aligha remélhetjük, hogy lesz valaki, aki kivezet a sűrü, vad vadonból, ahova a 21. században bekeveredtünk.

Még soha annyi ember nem élt a Földön, mint most. Steven Pinker angolul 2011-ben megjelent könyvében magabiztosan azt írta, hogy „valószínüleg most éljük az emberiség történetének legbékésebb napjait" (Pinker 2018: 13). Tíz évvel később, a Kína és az USA között kibontakozni látszó konfliktus fenyegető árnyékában nem írná ugyanezt. Az emberiség problémája azonban nem egyszerűsíthető le a személy- és csoportközi erőszak megnyilvánulásaira.

A vírusjárvány csak egy a jövő sűrű, vad vadonjába vezető utak sorában. A klímaváltozás nap mint nap szembesít a természeti környezetet fenyegető katasztrófákkal, melyek negatív hatásait növeli a migráció, a terrorizmus és a globális társadalmi egyenlőtlenség (Gelencsér 2015). A világ visszavonhatatlanul a bizonytalanság korába lépett, amit Hankiss Elemér már egy évtizeddel ezelőtt meghirdetett (Hankiss 2013). Bennis és Nanus 1985-ben vezetők számára írott könyvükben az új kort négy egymással szorosan együttjáró tulajdonsággal jellemezték. Az első tulajdonság a változékonyság, melynek következtében megnehezült, ha éppen nem lehetetlenné vált a természeti és társadalmi történések előrejelzése. A második tulajdonság az élet egészét átható bizonytalanság. A harmadik tulajdonság a komplexitás, melynek következtében a hálózatosan összekapcsolódó különböző rendszerek összetevőinek kölcsönös függősége megnőtt. Nem meglepő, hogy ilyen körülmények között a megismerés során az emberek egyre több talányba ütköznek, melyeknek nincs egyértelmü megfejtése.

A kvantummechanika által leírt világ alapján tudjuk, hogy a változékonyság, a bizonytalanság, a komplexitás és a sokértelműség mindig is a lét jellemzője volt, amit a görög kor embere még jól tudott, de a későbbi korok embere elfelejtett. Heidegger szerint a görög korban a lét nézett az emberre, bevonva meghatározatlanságába, s ellentéteibe hajszolva, ellentmondásaival megjelölve felszólította a meghatározásra. A tudás az igazságot el nem rejtve meghagyta azt a létben. A görög felfogással ellentétben az újkor embere a létezőt szembenállóként maga elé helyezi, miáltal a létező tárggyá válik, a tudás az igazságot a létből kiszakítva csak annak képét adja.

A változás eredményeképpen a megismerő ember horizontjáról eltűnt az egész, s helyette egyre burjánzó részek tolakodtak elő, melyek mindegyikének megismerésére külön tudományok keletkeztek. A tudás célja a tárggyá tett létezők alávetése, technikai meghódítása, eszközként való hasznosítása lett (Heidegger 2006).

Az egyetemek tanulóikat szaktárgyak szerint különböző munkákra készítették fel, melyek feladatsorai a létezőbe hatoló intelligencia révén voltak megoldhatók. A modern kor hajnalán a természet- és társadalomtudományokat egységesen áthatotta a tudás expanziójába vetett hit, a tények kultusza.

Ezt az egységet törte meg 1968 diákforradalma. Ettől az évtől fogva az amerikai és nyugat-európai egyetemeken élesen szétváltak a természet- és a társadalomtudományok. Allan Bloom a múlt század nyolcvanas éveiben riasztó képet adott az amerikai egyetemi képzésről, kiemelve a természettudományok abszolút elkülönülését a társadalomtudo- 
mányoktól. A természettudományok művelői saját tudományágaik fontosságának tudatában teljesen függetlenítették magukat a társadalomtudósoktól és a bölcsészektől. Utóbbiak radikalizálódtak és marginalizálódtak (Bloom1983).

Időközben megjelent és kibontakozott az emberek és a dolgok internete, mely a létezők egyetemét hálózatosítva visszaállította a lét hajdanvolt határtalan, végtelen egységét. A megállíthatatlan digitális átalakulás a Föld minden pontján élő emberek életét érintette és a jövőben még inkább érinteni fogja.

Napjainkban zajlik az emberi agy és emberi kéz közreműködését nélkülöző kiberfizikai rendszerek müködésén alapuló negyedik ipari forradalom, mely mélyrehatóan megváltoztatja a gyártást és a kereskedelmet. Sokkal kevesebb ember, sokkal több terméket és szolgáltatást fog elöállítani sokkal több ember számára. Hazahozva a gyártást a negyedik ipari forradalom hatalmas versenyelőnybe hozza a fejlett országokat a fejletlenekkel szemben, fokozza az agyelszívást, felgyorsítja a fejletlen országokból a fejlett országokba irányuló migrációt (Schwab 2016).

Digitális környezetben az áruk, emberek mozgását biztosító közlekedés sokkal biztonságosabb, a környezetre sokkal kevésbé ártalmas lesz. Az „okos városokban”, a szenzorokkal bőven ellátott közutakon közlekedő autonóm közlekedési eszközöknek nem lesznek vezetőik, csak utasaik.

A termelés és a kereskedelem globális hálózatosodása kihívást jelent a nemzetállamok számára, melyek ha akarják, ha nem, meg kell teremtsék szervezeteik „égi mását”, értve ezalatt a felhő adta lehetőségek teljes igénybevételét. A papíralapú, fáradságos és költséges face to face irodai hivatalos érintkezéseket kiváltja az állampolgárokat a bölcsőtől a sírig kísérő digitális technológia, mely gyors, hatékony és tévedhetetlen.

A digitális átalakulás legnagyobb hozzáadott értéke az emberek egészségének megőrzésére, a már kialakult betegségek kezelésére hivatott egészségügyi szolgáltatások teljes megújulása lesz. Az életfontosságú testállapotok monitorozására alkalmas, mobil eszközökbe telepített érzékelők a betegségek korai előrejelzését teszik lehetővé. A különféle betegségek tüneteit rögzítő, folyamatosan bővülő nagy adatbázisokra telepített mesterséges intelligencia programok minden korábbihoz képest pontosabb diagnosztikát és hatékonyabb terápiát tesznek lehetővé. A nano- és genotechnológia a betegségek kezelésében lehetővé teszi az egyedi, testreszabott gyógykezelést (Kurzweil 2013).

A változások nem hagyják érintetlenül a kulturális tartalmakat. A korábban létrehozott kulturális tartalmak az elektronikus térben az eredet és a felhasználás helyétől függetlenül mindenki számára mindenütt hozzáférhetővé válnak, jelentősen megkönynyítve az oktatást, a kutatást és a művelődést. A $z$ újonnan keletkező kulturális tartalmak eleve az elektronikus térbe kerülnek, különböző platformokon, csatornákon, bármikor visszakereshetően.

A hálózatra kapcsolt mobil kommunikációs eszközök milliárdnyi ember számára teszik lehetővé, hogy bármikor, bárhol, bárkivel kommunikáljanak, bárhonnan, bármilyen tartalmat letöltsenek, feltöltsenek és megosszanak. A létrejött információs Kánaán kihívása válságos helyzetet teremtett az információk termelésére, terjesztésére szakosodott intézmények számára, melyek elveszítették korábban megkérdőjelezhetetlen monopóliumaikat és privilégiumaikat. A válság elsodorta a hitelesnek elfogadott tömegkommunikációs szerkesztőségeket, melyek helyét a közösségi média sokszereplős kommunikációs terében sikeres véleményirányítók (influencerek) vették át. 
A központi szerkesztőségek által müködtetett tömegkommunikációs médiumokat felváltották a sok központú, központilag ellenőrizhetetlen közösségi médiumok, melyek alaposan felforgatták a nyilvánosság szerkezetét. A változást sokan a demokrácia beteljesüléseként üdvözölték, hiszen az új közösségi platformok mindenki számára lehetőséget adtak arra, hogy hírek fogyasztóiból egyidejüleg hírek előállítóivá váljanak (HeimansTimms 2018). A valóság azonban rácáfolt az optimista várakozásokra. Olyan helyzet állt elő, melyet Arisztotelész a különféle államformák előnyeit és hátrányait tárgyaló művében a demokrácia elfajulásaként ír le, ahol „a nép, mint afféle egyeduralkodó, kizárólagos hatalomra törekszik, mert nem áll a törvény alatt, despotává lesz, s így a hízelgők tesznek szert tekintélyre" (Arisztotelész 1984: 183). A demokratikus rendszerekben megválasztásukért küzdő politikusok gyorsan felismerték a hízelgésben rejlő lehetőségeket, s választási kampányaikat a közösségi médiában terjesztett egyszerű, gondolkodást nem igénylő, könnyen befogadható, igaznak álcázott hazugságokra alapozták.

A társadalmi élet minden szférájába behatoló digitális átalakulás által érintett müködések során történtek soha nem múlnak el nyomtalanul. A dolgok és az emberek internete minden történés nyomát adatként megőrzi. Lesage regényében a sánta ördög leemelte a madridi házak tetejét, hogy megmutassa egy diáknak, hogy mi történik a házak falain belül. Az egyre növekvő hatalmas adatmennyiség a Big Data adta elemzési lehetőségek az adatok birtokosainak hasonló módon páratlan betekintést enged azok életébe, akiktől az adatok származnak (Czukier-Mayer-Schönberger 2014). Az emberek viselkedésére vonatkozó, folyamatosan keletkező adatok fölötti rendelkezés az orwelli fantáziákat meghaladó módon lehetőséget teremt a totális ellenőrzésre, az emberi lét lényegét képező szabadság elvételére (Zuboff 2019).

Nem kérdés, hogy a vírusjárvány, mely még korántsem ért véget, jelentősen meggyorsítja a digitális átalakulást. Az élet minden területét átható digitalizáció és a datafikáció következményeként egyre nagyobb számban és egyre több területen jelennek meg mesterséges intelligencia alkalmazások, amelyek fölöslegessé teszik az emberek által elvégzett munkát a gyártásban, a kereskedelemben, a szolgáltatásokban, az ügyintézésben. A mesterséges intelligencia ma már tervez, ellenőriz, felvilágosít, kriminalisztikai feladatokat lát el, szövegeket ír, fordít, zeneszámokat szerez, diagnosztizál, fogyasztói és politikai célcsoportokat azonosít. A nem komplex, rutinfeladatokat a nem is túl távoli jövőben a fejlett országokban emberek helyett mesterséges intelligencia alkalmazásokkal vezérelt, nagysebességü, széles sávú adattovábbításra alkalmas hálózatokhoz csatlakoztatott, egymással kommunikálni és tanulni képes robotok, botok végzik el.

Ma még nem tudjuk, hogy a radikálisan új technológiai környezet miként hat majd az emberekre, de az elöre látható, hogy nagyon sokan lesznek, akik elveszítik munkájukat. A probléma nem új. Az emberi munkát kiszorító gépesítés térhódítását látva Marx már a 19. században felveti a munka fokozatos eltünése nyomán bekövetkező szabadidő kihívását, amire ma a globális kapitalizmus „bullshit” munkahelyek müködtetésével, szükségesnek feltüntetett, fölösleges szükségleteket kielégítő áruk és szolgáltatások tömeges kínálatával reagál (Graeber 2020).

$\mathrm{A} z$ intelligens technológiák által munkátlanná tett emberekre nem lesz szükség mint ügyintézőkre, portásokra, gépkocsivezetőkre, betanított munkásokra, de hasonló sors várhat a közjegyzőkre, az újságírókra, a kézbesítőkre. El fog tűnni minden olyan foglalkozás, melynek meglepetésmentes feladatstruktúrája algoritmizálható. Másfelől soha nem látott mértékben szükség lesz kreatív, innovatív, kritikai gondolkodású emberek- 
re, akik feladata a digitális technokörnyezet karbantartása, fejlesztése, megújítása lesz. Ezeknek a feladatoknak az ellátása speciális intelligenciát és speciális tudást igényel, amire csak a legtehetségesebbek és a legképzettebbek lesznek képesek. Ugyancsak szükség lesz olyan emberekre, akik nem komplex, de egyedi kihívásokkal teli feladatokat kell ellássanak, mint például a gyermeknevelés, a testi és lelki betegek ápolása, rehabilitációja. Az új munkakörök feltehetően kevesebb számú embert fognak felvenni, mint ahányan fölöslegessé válnak. E tömeg speciális problémáinak megértése, kezelése a szociális munkások, a közgazdászok, a szociológusok, a kulturális antropológusok feladata lesz. A fölöslegessé vált embereket meg kell tanítani élni egy olyan világban, mely nem ad nekik munkát, de helyette egy olyan életet kínál, melynek örömeit, lehetőségeit nekik maguknak kell felfedezni. Játszhatnak, alkothatnak, társas életet élhetnek, szerethetnek, segíthetnek, képezhetik magukat, éppen úgy, mint a nyugati országokban élő nyugdíjasok, akik új életet teremthetnek maguknak, ha akarnak. A fölöslegessé vált emberek egzisztenciájának alapját a garantált minimális alapjövedelem képezheti, mely nélkül a 4.0 ipar termékeinek és szolgáltatásainak nem lenne piaca. Nagy lehetőségek várnak a művészetekre, melyek, amennyiben megérdemlik ezt a nevet, soha nem lesznek algoritmizálhatók.

A mesterséges intelligencia alkalmazások szükségtelenné teszik a szakterületek által feldarabolt tudás átadását embereknek. Az alapfokú (négyéves) oktatási intézmények szerepe változatlan marad, feladatuk az írni-olvasni tudás és a számolás megtanítása, a társas élethez szükséges kommunikációs és szociális készségek kialakítása, a saját testre fordított figyelem, az egészséges életmód tudatosítása. A középfokú oktatási intézmények feladata a természet- és társadalomtudományok alapjainak megismertetésére alkalmas, a kollaboratív, projekt alapú tevékenységekhez szükséges készségek kialakítása (Csepeli-Szathmáry-Murányi 2020).

A z egész társadalmat megváltoztató digitális átalakulás alapvetően a felsőoktatást érinti.

A z egyetemek már régóta sorra indítanak az elektronikus térben elérhető kurzusokat, elérhetővé téve meghirdetett szakjaik elvégzését anélkül, hogy a hallgatók és a tanárok közös fizikai térben láthatják-hallhatják egymást. A felsőfokú tudást kínáló intézmények globális online versenytérbe kerültek, ahol meg kell küzdeniük a hallgatókért. A felsőoktatási intézményeknek szembe kell nézniük a ténnyel, hogy amit tanítanak a diákoknak, az számtalan más forrásból is elérhető. A versenyben az győz, akinek a legmagasabb a presztízse, legnagyobb a hírneve, megbecsülése.

$\mathrm{A} z$ online felsőoktatási térbe való belépés küszöbe viszonylag alacsony. Ennek következtében hiába a presztízs és a reputáció, senki sem ülhet nyugodtan babérjain, mindig jöhet egy kihívó, aki frissebb, újabb, használhatóbb tudást ígér, s ígéretét valóra is váltja. De akár régi, akár új felsőoktatási intézményről van szó, sikerre csak az számíthat, amelyik szakít a hagyományos, tanszéki és intézeti logika szerint feldarabolt tudáskínálattal, s rugalmas, interdiszciplináris, innovatív tudást kínál.

Ami emberi agy és emberi kéz nélkül ellátható feladat, arra embert többé nem kell felkészíteni. Bőven marad azonban tudnivaló, melynek elérése a tudás globális digitális piacán az egyetemek, főiskolák és alternatív tudásközvetítő csatornák közötti versenyben lesz lehetséges. A szakok szerint felparcellázott, oklevéllel hitelesített tudást speciális feladatok ellátására összeállított tudáscsomagok váltják fel, melyek érvénye addig tart, amíg egy új feladat nem keletkezik. Ezáltal a felsőoktatásban részt vevők élethossziglan 
tanulásra kell hogy elkötelezzék magukat, már amennyiben munkát akarnak végezni. A megújult tudáskínálat centrumában az emberektől elhagyott, mesterséges intelligencia alkalmazások során át ellátott feladatok körének szélesítésére, mélyítésére alkalmas fejlesztői tudás áll majd, mely jóval több, mint alapos matematikai és informatikai tudáson alapuló technológiai ismeretek együttese. Csak annak a fejlesztésnek lesz esélye a sikerre, mely abból indul ki, hogy a digitális létezésben a realitás és a virtualitás tartományai közötti határvonal elmosódik, s a technológia fejlesztője és felhasználója a létrejövő hibrid valóság két egyenrangú szereplője (Ropolyi 2006).

A lét egészében rejlő igazság visszavétele nem jelenti a hagyományos szakok szerinti tudás eltűnését a tudás piacáról. Ellenkezőleg, a lét meghatározatlanságával szembesülő ember akkor lesz képes a meghatározásra, ha továbbra is számíthat a szakok szerinti tudás megszerzésére, melynek már nem a létezők tárggyá tétele, alávetése, eszközként való hasznosítása a célja, hanem a lét üzenetének meghallása és megértése. Ez csak akkor lesz lehetséges, ha szövetségre lép a matematika és a filozófia, a természettudományok szakítanak az Allan Bloom által leírt „splendid isolation” politikájával és párbeszédet kezdenek a társadalom- és bölcsészettudományokkal.

$\mathrm{A} z$ interdiszciplináris párbeszéd színhelyei a korábban kivételesnek számító, de az új helyzetben rendszeresen müködő, magyarra nehezen lefordítható Advanced Studies nevű intézetek, ahol az egyetemekről, kutatóintézetekből és az üzleti szférában működő kutatási-fejlesztési intézetekből érkező, magasan képzett legjobb oktatók és kutatók találkoznak, és kurzusokat kínálnak a kemény versenyben kiválogatott hallgatóknak, akik az új tudást létrehozó és elosztó intézmények utánpótlási bázisát képezik.

A 2019-ben kitört vírusjárvány előbb vagy utóbb véget ér. Semmi garancia nincs azonban arra, hogy hasonló járványok nem következnek be a jövőben (Brooks et al. 2020). Bebizonyosodott, hogy egyes munkafeladatok végzésében, valamint az oktatás és képzés közvetlen fizikai érintkezést nem igénylő válfajaiban (előadásokban, szemináriumokban) a fertőzésveszély nullára csökkenthető a digitális platformokra való áttérés révén. A vírusjárvány alatt digitális platformokra kényszerült oktatás és a képzés pozitív tapasztalatai a felsőfokú oktatásban továbberősítik a digitális átállás hadállásait. A tapasztalati tudás átadásának csak offline térben lehetséges helyszínei ugyan megmaradnak, de csak addig, amíg a virtuális realitás technológiák nem lesznek képesek a fizikai valóság teljes értékủ helyettesítésére.

A rugalmas, interdiszciplináris, élethossziglani tanulásra alkalmas globális tudáspiacon a különböző tudáscsomagokat kínáló versenyző intézmények közötti verseny kegyetlenül szelektál. A versenyben kevés intézmény lesz, melyek igen sok hallgatót vonzanak, és sok intézmény lesz, melyeknek külön-külön kevés hallgatójuk lesz. A vonzerő nem kismértékben azon múlik, hogy a tudást kínáló intézményeknek kik a vezető, meghatározó alakjai, akiket nem lehet kinevezni, saját tudományos teljesítményük teszi nagygyá őket. A személyes tudományos hírnév és az intézményi hírnév szorosan összefügg egymással. A sikeresek skálafüggetlen eloszlását Benoit Mandelbaum Jézus Máté evangéliumában olvasható mondása alapján Máté-effektusnak nevezi, mely szerint: „akinek van, annak adatik és bővelkedik és bővelkedni fog, akinek pedig nincs, attól az is elvétetik, amije van." (Mt. 13.12.)

Az Európai Unió döntéshozói 2000-ben helyesen ismerték fel, hogy az Unió globális versenyképességének alapfeltétele a tudásalapú gazdaság megteremtése. A célt azonban az Unió csak részben érte el, a nemzetközi versenyben lemaradt (Körösi 2012). A kudarc 
tanulságait az Unió vezetői nem vonták le. Minden évtized végén konstatálják a cél el nem érését, melynek elérését a következő évtized végére tüzik ki. A kudarc egyik oka, hogy az Unió döntéshozói a tudás meghatározó szerepét bürokrata és technokrata módon a gazdasági szférára korlátozták, kihagyva belőle a társadalom- és bölcsészettudományokat, s egészében véve a kultúrát.

Szerencsésebb lett volna tudásalapú társadalomról beszélni, melyben együtt van a gazdaság és a kultúra. Az Unió központi költségvetésében ugyan a pénz elosztói biztosítottak forrásokat a kutatás-fejlesztés, a tudomány és a felsőfokú oktatás támogatására, de a tudás létrehozására, terjesztésére szánt összegek rendre alatta maradtak a versenyképesség szempontjából irreleváns mezőgazdasági támogatásokra adott pénzekhez képest.

A kudarc másik oka, hogy a döntéshozók a tudásalapú gazdaság megteremtésére rossz eszközt választottak, rábízva az egyes tagállamokra a cél elérését. Az Unió vezetése, a Bizottság, a Tanács és a Parlament nem ismerte fel, hogy a tudás termelése, disztribúciója kilép a nemzetállami keretekből, s a globalizálódó tudáspiacon csak azoknak a nem feltétlenül állami pénzekből élő szereplőknek van esélyük, akik mindenütt elérhetők, mindenütt jelen vannak a világban, mindenhonnan rekrutálnak kiemelkedően sikeres és teljesítőképes tudósokat, kutatókat, fejlesztőket.

Idő kérdése, hogy 21. században óriásnyira növekedett információgyüjtő, termelő és elosztó globális hatósugarú üzleti szervezetek (Google, Amazon, Facebook, Alibaba) az egyetemekkel, kutatóintézetekkel összefogva mikor fognak a legkülönbözőbb célcsoportok számára tudásszolgáltatásokat nyújtani.

A nemzetállamok speciális feladata, hogy a kibontakozó nemzetközi tudáspiacon a nyelvi egyensúly felborulása ellen védekezzenek. A világon ma élő 8000 nyelv mintegy 40\%-a kihaló félben van (Kornai 2013). A maradék 60\% közül azonban csak igen kevés nyelvnek van esélye arra, hogy bekerüljön a globális tudáspiac vérkeringésébe. A tudományos kommunikáció lingua francája az angol, mely a klasszikus angol nyelv leegyszerűsített, a tudományos kommunikáció által megkövetelt szókészletre szűkített változata. Az egyes nemzetállamoknak maguknak kell gondoskodniuk arról, hogy megfelelő fordítóprogramok álljanak rendelkezésre ahhoz, hogy polgáraik anyanyelvükön is képesek legyenek tudományos problémák megfogalmazására, előadására, megértésére. A természettudományi kommunikációban az angol nyelv vezető szerepe megkérdőjelezhetetlen. A társadalom- és bölcsészettudományok kutatási kérdései azonban inkommenzurábilisak, elválaszthatatlanok a nyelvi közegtől, melyben születtek és élnek.

Az egységes angol nyelvi platform a társadalom- és bölcsészettudományokat elszegényíti, kilúgozza.

A politikai, kulturális, vallási, etnikai határokat nem ismerő vírusjárvány globálisan leértékelte a személyes jelenlétet, melynek helyét a munkában, a szabadidő eltöltésében átvette a digitális jelenlét. Ma még nem tudni, mennyire lesznek tartósak a változások, de feltehető, hogy egyre több szervezet tereli át működését digitális platformokra, melyek használata fölöslegessé teszi a drága irodahelyiségek fenntartását, az alkalmazottak, üzlettársak, ügyfelek ide-oda utazását. Válságba kerültek a közvetlen személyközi találkozásokra épülő gazdasági ágazatok, kiürültek a szállodák, az éttermek, a sokak által látogatott tömegszórakoztató helyek. Jóval kevesebben, jóval kevesebb helyre utaznak, mint korábban. Az online kereskedelem lerövidíti az áruk és a fogyasztók közötti utat, megtizedelve az áruházakat, boltokat. 
A vírusjárvány következményei megfordították az eddig töretlennek hitt globalizációs trendet. Az emberi élet fizikai dimenziói visszahúzódtak a lokális terekbe, ahol az egymással közvetlen kapcsolatban álló emberek közvetlen találkozásai zajlanak. A fizikai terekben nem megoldható feladatok megoldása áttevődött digitális platformokra. Ez történt az oktatásban, a tudományos kommunikációban, a pszichoterápiában, $\mathrm{s}$ a home office-ra áttért munkakörökben. Az új irány nem kifele, hanem befele vezet, ahol csak magunk és legközelebbi társaink vagyunk ott.

Az episztemológiai értelemben vett tudás privilégiumát a jövőben várhatóan elragadják az emberektől az erős mesterséges intelligenciával rendelkező eszközök. A robotok és botok hálózatosan egybekapcsolódva, a felhasználók folyamatosan nyomon követett tevékenységéből származó adatokból kiszürt algoritmusok alkalmazásával radikálisan megújítják a 21. század emberének életét, beleértve a képzését és az oktatását is.

A jövő horizontján azonban nemcsak bárányfelhők, viharfelhők is láthatók. A planetáris idiotizmus mindenkit ellenőrző hatalmi tébolya, a tömegesség, az emberek számításokon alapuló osztályozása, az öncélú technológiai tökéletesedés következményeként az ember kívül esik a lét tekintetén, magára marad a hátborzongató idegenségében.

$\mathrm{A} z$ emberiség válaszútra érkezett, $\mathrm{s}$ csak akkor találhat rá a jó útra, ha visszatalál az értékekhez, melyek lehetővé tették a megmaradást a Földön. Mint Rutger Bregman írja, a homo sapiens a neandervölgyi emberhez képest ostobább és gyengébb volt, de a túlélési versenyt mégis a homo sapiens nyerte meg. Ennek oka Bregman szerint az, hogy a homo sapiens tudott valamit, amit a neandervölgyi nem tudott. A homo sapiens tudott mosolyogni, barátkozni, s ami a legfőbb, tudott együttműködni társaival. A barátságosságnak persze vége lett ott, ahol a saját csoport által teremtett társas valóság véget ért, de a saját csoporton belül a szolidaritás, az altruizmus, a bizalom megtartotta az egyes csoportokat az időben, annak ellenére is, hogy más csoportokkal ádáz harcot vívtak a megmaradásért és a növekedésért (Bregman 2020).

$\mathrm{A} z$ új technológia által teremtett mesterséges tudás eszközei, programjai, algoritmusai sosem lesznek képesek arra, hogy az emberi élet teljességéhez szükséges axiológiai tudást létrehozzák, sosem fognak válaszolni arra a kínzó kérdésre, melyet Tamási Áron Amerikába keveredett hőse tett fel a templomból kilépő, az ördögöt éppen elvetélő fekete embernek, megkérdezve tőle, hogy „A maga lelke most tiszta, mondja meg tehát nekem, hogy mi célra vagyunk a világon?" A kérdésre a fekete ember arca megmerevedett, mélyen Áron szemébe nézett, s azt válaszolta: „Azért vagyunk a világban, hogy valahol otthon legyünk benne."

A vírusjárvány jó alkalom arra, hogy megkeressük az otthont a transzcendentális hajléktalanságban.

\section{IRODALOM}

Arisztotelész (1984) Politika. Budapest, Gondolat. Ford. Szabó Miklós.

Bennis, W. \& Nanus, B. (1985) Leader: Strategies for Taking Charge. New York, Harper and Row Publishers.

Bloom, A. (1987) The Closing of the American Mind. New York, Simon Schuster.

Bregman, R. (2020) Humankind. A Hopeful History. London, Bloomsbury Publishing.

(Transl. by Elizabeth Manton, Erica Moore) 
Brooks, D. R., Hoberg, E. P., Boeger, W. A., Gardner, S. L., Araujo, S. B. L., Bajer, K. K., Botero-Cañola, S., Byrd, B., Földvári, G., Cook, J. A., Dunnum, J., Garamszegi, L. Zs., Herczeg, D., Juarrero, A., Jakab, F., Kemenesi, G., Kurucz, K., León-Règagnon, V., Mejía-Madrid, H. H., Molnár O., Nisbett, R. A., Preiser, W., Stuart, M., Szathmary, E., Trivellone, V. \& Altangerel Tsogtsaikhan Dursahinhan (2020) Mielőtt véget ér a pandémia, gondoskodjunk, hogy ne történhessen meg újra. Szabad Piac, No. 2. pp. 25-32.

Cukier, K. \& Mayer-Schönberger, V. (2014) Big Data-Forradalmi módszer, mely mgváltoztatja munkánkat, gondolkodásunkat és egész életünket. Budapest, HVG könyvek. (Ford. Dankó Zsolt)

Csepeli Gy., Szathmáry E. \& Murányi I. (2020) Kooperációs kísérlet osztályteremben. Educatio, Vol. 29. No. 1. pp. 108-115.

Gelencsér A. (2015) Füstbe ment bolygó. Veszprém, Pannon Egyetem.

Graeber, D. (2020): Bullshit munkák. Budapest, Typotex. (Ford. Boross Ottilia)

Hankiss E. (2013) Európa, két világ között. Magyar Tudomány, Vol. 174. No. 11. pp. 1386-1395.

Heidegger, M. (1938) (2006) A világkép kora. In: Rejtekutak. Budapest, Osiris. pp. 70102. (Ford. PÁlfalusi Zsolt)

Heimans, J. \& Timms, H. (2018) New Power: How Power Works in our Hyperconnected World and How It to Make Work for You. New York, Doubleday.

Kornar A. (2013) Digital Language Death. PLoS ONE, Vol. 8. No. 10. p. e77056. https:// doi.org/10.1371/journal.pone.0077056

KöRösı I. (2012) Az Európa 2020 stratégia, az Euréka szerepe és kilátásai. MTA Közgazdasági és Regionális Tudományi Kutatóközpont. Világgazdasági Intézet. Kibivások, 205. sz.

Kurzweil, R. (2013) A szingularitás köszöbén. Budapest, Ad Astra.

Pinker, S. (2011) The Better Angels of out Nature: Why Violence Has Declined? New York, Penguin. (Magyarul: Az erőszak alkonya - Hogyan szelídült meg az emberiség?) 2018. Budapest, Typotex. (Ford. Gyárfás Vera)

Ropoly L L. (2006) Az internet természete. Budapest, Typotex.

Schwab, K. (2016) The Fourth Industrial Revolution. New York, Crown Publishing.

Zuboff, S. (2019) The Age of Surveillance Capitalism: The Fight for a Human Future at the New Frontier of Power. London, Profile Books.

A cikk a Creative Commons Attribution 4.0 International License (https://creativecommons.org/licenses/ by/4.0/) feltételei szerint publikált Open Access közlemény, melynek szellemében a cikk bármilyen médiumban szabadon felhasználható, megosztható és újraközölhető, feltéve, hogy az eredeti szerző és a közlés helye, illetve a CC License linkje és az esetlegesen végrehajtott módosítások feltüntetésre kerülnek. (SID_1) 